\title{
PENERAPAN STRATEGI FUNDRAISING DI SAVE THE CHILDREN INDONESIA (FUNDRAISING STRATEGY IMPLEMENTATION IN SAVE THE CHILDREN INDONESIA)
}

\author{
oleh \\ Yessi Rachmasari ${ }^{1}$, Soni Akhmad Nulhaqim ${ }^{2}$, Nurliana Cipta Apsari ${ }^{3}$ \\ ${ }^{1}$ Alumni Program Studi Kesejahteraan Sosial, Fakultas Ilmu Sosial dan Ilmu Politik, Universitas Padjadjaran
2 Dosen Departemen Kesejahteraan Sosial, Fakultas Ilmu Sosial dan Ilmu Politik, Universitas Padjadjaran
${ }^{3}$ Dosen Departemen Studi Kesejahteraan Sosial, Fakultas Ilmu Sosial dan Ilmu Politik, Universitas Padjadjaran \\ Email: yessirachma19@gmail.com; Soni.nulhaqim@unpad.ac.id; nurliana.cipta.apsari@unpad.ac.id
}

\begin{abstract}
ABSTRAK
Penelitian ini bertujuan untuk menggambarkan strategi fundraising yang dilakukan oleh Save The Children Indonesia meliputi strategi dialogue fundraising, strategi corporate fundraising, strategi multichannel fundraising, strategi retention and development donor. Strategi fundraising ini sebagai salah satu upaya Save The Children Indonesia untuk mendapatkan sumber pendanaan dalam menjalankan aktivitas dan program kegiatannya, melalui strategi fundraising ini Save The Children Indonesia dapat mengurangi ketergantungan dengan lembaga donor utama.

Metode penelitian yang digunakan adalah metode penelitian deskriptif dengan pendekatan kualitatif, dan teknik studi kasus. Teknik pengumpulan data ialah wawancara mendalam, observasi nonpartisipasi, studi kepustakaan dan studi dokumentasi. Teknik analisis dan pengolahan data ialah reduksi data, penyajian data (display data), dan verifikasi data. Penelitian ini melibatkan sembilan informan, yang terdiri dari, pengurus dalam unit divisi fundraising, fundraiser, donatur individu dan penerima donasi. Penentuan informan dilakukan berdasarkan tujuan penelitian untuk menggali lebih dalam mengenai penerapan strategi fundraising yang dilakukan oleh Save The Children Indonesia.

Hasil dari penelitian ini adalah penerapan strategi dialogue fundraising yang dilakukan oleh Save The Children Indonesia ini melalui proses tatap muka dari donor potensial. Penerapan strategi corporate fundraising menggunakan pendekatan kemitraan internasional dan lokal. Penerapan strategi multichannel fundraising mengumpulkan dana melalui berbagai saluran, melalui telefeundraising, online fundraising, crowdfunding dan community fundraising. Untuk penerapan strategi retension and development donor dalam mempertahankan kepercayaan para donaturnya melalui pelayanan yang diberikan ialah kepemilikan legalitas, kemudahan mendapatkan pelayanan informasi, kemudahan pembayaran, laporan pertanggungjawaban keuangan dan kegiatan, dan giving thanks. Namun, dalam strategi fundraising yang dilakukan oleh Save The Children Indonesia ternyata masih belum optimalnya sosialisasi Save The Children Indonesia kepada masyarakat dan belum adanya kerjasama dengan perusahaan lokal. Dengan demikian, peneliti menyarankan program Corporate Fundraising as a Fundraising Strategy: "Save a Child, Galang Dana Pembuatan Rumah Pintar Untuk Anak Jalanan".
\end{abstract}

Kata kunci: strategi fundraising, Save The Children Indonesia

\section{ABSTRACT}

This study aimed to describe the fundraising strategy conducted by Save the Children Indonesia include dialogue fundraising strategy, corporate strategy, fundraising, fundraising multi channel strategies, retention strategies and donor development. This fundraising strategy as an effort to Save the Children Indonesia for obtaining funding in running the activities and program of 
activities, through this fundraising strategy Save the Children Indonesia can reduce dependence with major donors.

The method used is descriptive method with qualitative approach and case study technique. Data collection techniques are in-depth interviews, observation non partisipasi, literature study and documentation study. Analysis techniques and data processing is data reduction, data presentation (display data), and verification of data. The study involved nine informants, consisting of, your Board division unit fundraising, fundraisers, individual donors and beneficiaries of donations. Determination of informants depends on the purpose of research implementation of a fundraising strategy conducted by Save the Children Indonesia.

The results of this study can be seen that the implementation of a fundraising strategy dialogue conducted by Save the Children Indonesia is through the face of a potential donor. Application of corporate fundraising strategy using international and local partnership approach. Implementation of multichannel fundraising strategy to raise funds through various channels, through telefeundraising, online fundraising, crowdfunding and community fundraising. For the implementation of the strategy and development retension donor in maintaining the confidence of donors through the service provided is legal ownership, access to information services, ease of payment, financial accountability and activity reports, and giving thanks. However, in a fundraising strategy conducted by Save the Children Indonesia was still not optimal due to socialization Save the Children Indonesia to the community and the lack of cooperation with local companies. Thus, the researchers suggest program as a Corporate Fundraising Fundraising Strategy: "Save a Child, Fundraising Making Smart House For Street Children”.

Keywords: fundraising strategy, Save the Children Indonesia

\section{PENDAHULUAN}

Keberhasilan sebuah organisasi pelayanan sosial dalam menjalankan setiap aktivitasnya tidak luput dari manajemen pelayanan sosial dari setiap organisasi pelayanan sosial tersebut. Seringkali yang dialami oleh organisasi pelayanan sosial yaitu terkait permasalahan pendanaan dan biasanya permasalahan tersebut akan mempengaruhi aktivitas dari organisasi pelayanan sosial itu sendiri. Fenomena yang terjadi saat ini terdapat organisasi pelayanan sosial yang mengalami kegelisahan dan keruntuhan terkait sektor pendanaan. Di Indonesia sendiri, juga tidak sedikit organisasi pelayanan sosial yang menghentikan aktivitasnya akibat kekurangan dana. Tri Iswardani yang merupakan aktivis masyarakat mengatakan banyaknya organisasi pelayanan sosial yang bergerak pada penanggulangan narkoba gulung tikar akibat ketiadaan dana (www.tempo.co.id, 18/12/13). Fenomena lain terkait ketiadaan dana yang dialami oleh organisasi pelayanan sosial dari data yang dihimpun oleh Tim Public Interest Research and Advocacy Center (PIRAC) 3 besarnya bantuan dana asing untuk programprogram organisasi pelayanan sosial semakin menurun jumlahnya dari setiap tahunnya, sehingga banyak organisasi pelayanan sosial yang menjalankan program tidak maksimal, bahkan tidak sedikit yang terpaksa "gulung tikar" (www.pirac.org). 
Peristiwa semacam ini menunjukkan bahwa dalam sebuah organisasi pelayanan sosial memerlukan energi untuk mengadakan kegiatan fundraising. Kettner (2002) mengemukakan terdapat lima aspek manajemen dalam organisasi pelayanan sosial, antara lain yaitu: Planning, Organizing, Budgeting, Human Resources Development, dan Informasi System. Kelima aspek tersebut berfungsi untuk menunjang kinerja dari program-program organisasi pelayanan sosial dalam mencapai tujuan sebuah organisasi. Kelima aspek yang telah dikemukakan oleh Kettner tesebut, terdapat salah satu aspek yang berfungsi untuk menjaga keseimbangan organisasi pelayanan sosial agar dapat bertahan hidup dan mencapai tujuannya, yaitu aspek budgeting yang didalamnya mencakup sumber pendanaaan dari organisasi pelayanan sosial yang diperoleh dari kegiatan fundraising.

Fundraising sebagai salah satu kegiatan pendanaan yang mempunyai pengaruh dalam keberlanjutan sebuah organisasi pelayanan sosial. Selain itu, fundraising digunakan untuk menjaga keseimbangan organisasi pelayanan sosial dalam membiayai aktivitas program dan operasional organisasi pelayanan sosial. Maraknya aktivitas fundraising saat ini yang dilakukan oleh organisasi pelayanan sosial, maka diperlukan strategi fundraising dengan memanfaatkan potensi dan sumber-sumber yang ada di organisasi pelayanan sosial tersebut. Kondisi yang terjadi saat ini, organisasi pelayanan sosial dalam melakukan fundraising tidak ditunjang dengan strategi fundraising yang efektif. Hal ini diperkuat oleh penelitian Kilbey (2008:5) sebagai berikut: Sekitar 65 sampai 75 persen dari organisasi yang disurvei telah tertulis dan jarang menggunakan strategi pendanaan yang baik. Namun, analisis laporan keuangan organisasi oleh Lotvonen (2005) mengungkapkan bahwa hanya 13 persen dari organisasi yang memiliki strategi pendanaan yang aman secara finansial dan berkelanjutan. Non Profit Organization memiliki strategi penggalangan dana yang tidak koheren, mungkin karena kurangnya praktek manajemen yang baik.

Berdasarkan penjelasan tersebut, strategi fundraising yang dilakukan oleh organisasi pelayanan sosial dalam melakukan kegiatan fundraising perlu hendaknya disesuaikan dengan kebutuhan yang disesuaikan oleh tujuan dari organisasi pelayanan sosial tersebut. Strategi fundraising diperlukan oleh organisasi pelayanan sosial dalam melakukan kegiatan fundraising untuk menciptakan cara penggalangan dana yang berbeda agar memudahkan para donatur yang ingin berdonasi. Berbagai teknik dan metode yang dilakukan oleh organisasi pelayanan sosial untuk menciptakan strategi fundraising yang efektif untuk menarik simpatisan para donatur. 
Hasil riset PIRAC mencatat besarnya potensi sumbangan masyarakat Indonesia lebih dari Rp. 12,3 trilyun per-tahun dan baru sekitar $10 \%$ berhasil digalang oleh lembagalembaga di Indonesia. Artinya masih ada 90\% lagi yang belum digalang secara optimal. Dalam hal ini, tim PIRAC melihat penggalangan dana yang optimal dengan menggunakan metode sebagai strategi fundraising yang dilakukan oleh organisasi pelayanan sosial. Berikut ini, metode fundraising sebagai bagian dari strategi fundraising yang dilakukan oleh organisasi pelayanan sosial ditunjukkan pada grafik dibawah ini.

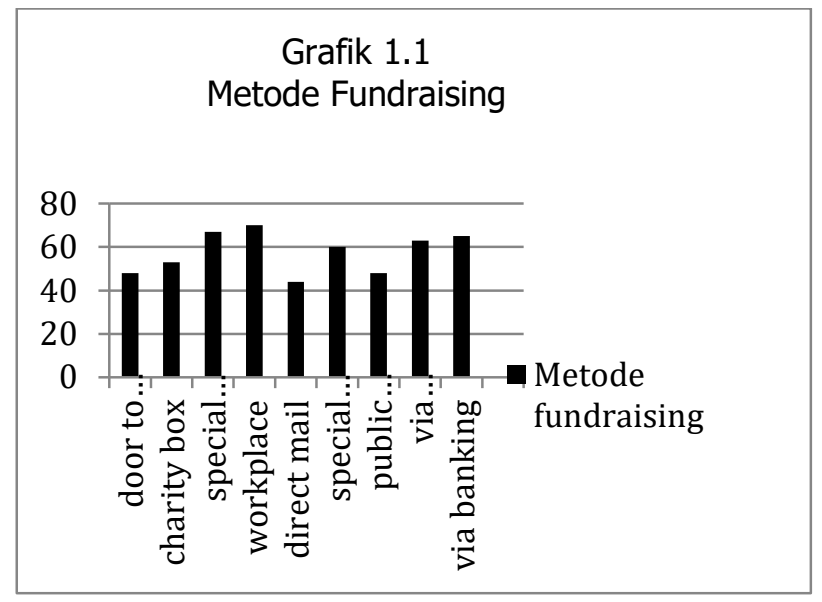

Sumber: Hasil Survey PIRAC

Berdasarkan grafik hasil survey tim PIRAC tersebut, penjelasan grafik tersebut yaitu organisasi pelayanan sosial menggunakan metode yang dilakukan di tempat kerja (workplace) dengan menggunakan strategi face to face fundraising sekitar 70 persen, melalui telepon 65 persen dan masyarakat berdonasi melalui penyelenggaran acara (special event) sebesar 45 persen. Selanjutnya, terdapat juga organisasi pelayanan sosial yang menggunakan direct mail maupun iklan layanan masyarakat sekitar 45 persen dengan menggunakan strategi beragam saluran dalam melakukan kegiatan fundraising. Metode tersebut digunakan sebagai salah bentuk strategi yang dilakukan oleh organisasi pelayanan sosial untuk mencapai tujuannya dalam mengajak masyarakat untuk dapat berdonasi.

Disisi lain, strategi fundraising juga dimanfaatkan dalam alternatif peluang peningkatan sumber pendanaan dan untuk menjaga keberlanjutan kegiatan organisasi pelayanan sosial. Pada saat ini ditengah persaingan organisasi pelayanan sosial dalam melakukan fundraising, hal ini perlu didukung dengan strategi fundraising dalam penciptaan inovasi sebagai dukungan sumber pendanaan. Penyataan ini diperkuat oleh Irfan (2011) terkait pentingnya melakukan strategi fundraising dalam melakukan penggalangan dana, yaitu; Organisasi nirlaba menyadari bahwa mereka tidak dapat terus menerus bergantung pada sumber-sumber pendukung tradisional saja dan mereka sekarang harus benar-benar independent atau tidak tergantung. Hal ini berakibat pada meningkatnya perhatian terhadap prinsip-prinsip manajemen profesional yang menghasilkan pendapatan internal yang lebih baik. Situasi inilah yang 
mendorong beberapa lembaga pengelola danadana sosial untuk melakukan strategi dengan menciptakan inovasi. Meskipun sesungguhnya kegiatan penggalangan dana (fundraising) adalah berguna juga bagi kegiatan operasional lembaganya, namun tetap menjadi image yang tidak baik jika terfokus hanyalah untuk mengejar uang semata.

Berdasarkan pernyataan tersebut, pentingnya strategi fundraising dalam aktivitas fundraising tidak terfokus hanya mengejar kepada penciptaan sumber-sumber pendanaan saja. Tetapi, dapat menjaga kepercayaan kepada masyarakat terhadap pelayanan yang diberikan oleh organisasi pelayanan sosial tersebut. Sehingga, strategi fundraising yang dilakukan oleh organisasi pelayanan sosial dilakukan dengan efektif dan penciptaan inovasi baru untuk meningkatkan sumber pendanaan dan kualitas pelayanan kegiatan dalam membangun kepercayaan kepada masyarakat.

Pada saat ini, oganisasi pelayanan sosial yang mampu bertahan hingga saat ini dalam menjalankan setiap aktivitas biasanya didukung dengan strategi fundraising sebagai salah satu langkah pencapaian tujuan tersebut. Salah satu organisasi pelayanan sosial yang hingga saat ini masih mampu bertahan dalam menjalankan aktivitas pelayanan sosial di tengah maraknya organisasi pelayanan sosial yang bermunculan, yaitu Save The Children Indonesia.

\section{Save The Children Indonesia}

merupakan salah satu organisasi pelayanan sosial internasional yang berfokus pada kepedulian terhadap isu-isu dan pemberian pelayanan yang berkaitan tentang kesejahteraan anak. Save The Children Indonesia terletak di Taman Margasatwa No. 26 C Jakarta Selatan. Save The Children Indonesia telah ada di Indonesia sejak tahun 1976. Pada saat ini Save The Children Indonesia sudah berdiri hampir 39 tahun tentu saja tidak dapat selalu mengandalkan dana dari lembaga donor dalam melakukan aktivitasnya. Aktivitas yang dilakukan oleh Save The Children Indonesia saat ini dalam perlindungan dan pemenuhan kebutuhan anak perlu didukung dengan manajemen pelayanan sosial yang baik. Salah satunya yaitu aspek pendanaan yang diperoleh melalui fundraising dalam menjalankan setiap kegiatannya. Oleh karena itu, kegiatan fundraising yang dilakukan tersebut didasarkan pada strategi fundraising yang telah dirancang dan disesuaikan berdasarkan kebutuhan dan tujuan organisasi. Salah satu tujuan organisasi pelayanan sosial menggunakan strategi fundraising dalam menjalankan aktivitas fundraising yaitu untuk dapat mempertahankan keberlangsungan organisasinya. Hal ini diperkuat oleh (Tedham, 2012: 25) sebagai berikut: Mendapatkan dukungan dalam hal keuangan tentu saja diperlukan oleh organisasi untuk dapat secara efektif menjalankan program dan kegiatan 
yang dilakukan oleh organisasi pelayanan sosial. Banyaknya organisasi pelayanan sosial yang ada, tentu saja terjadi kompetisi besar dan sumber daya biasanya selalu terbatas. Organisasi pelayanan sosial saat ini membutuhkan penggalangan dana yang professional dan kreatif, terus mencari strategi yang inovatif dan efektif untuk mendorong dukungan para pendonor.

Organisasi pelayanan sosial yang telah lama berdiri tentunya menyusun dan menggunakan strategi fundraising agar dapat mencapai tujuan organisasi sehingga dapat bertahan hingga saat ini. Kegiatan fundraising yang dilakukan oleh Save The Children Indonesia berupaya dalam menggunakan strategi fundraising yang efektif maupun inovatif dan disesuaikan dengan kebutuhan Save The Children Indonesia. Pada saat ini kegiatan fundraising yang dilakukan oleh Save The Children Indonesia telah berjalan selama kurang lebih 2 tahun pada tahun 2016 ini yang dimulai melakukan penggalangan dana pada tahun 2014. Kegiatan fundraising yang dilakukan oleh Save The Children Indonesia dimulai pada tahun 2014 karena baru mendapatkan perizinan resmi dari Kementerian Sosial terkait pengumpulan sumbangan (donasi). Salah satu alasan utama Save The Children Indonesia melakukan fundraising yaitu agar Save The Children Indonesia tidak selalu bergantung terhadap donor utamanya yaitu Save The Children
Internasional. Dalam menjalankan aktivitas fundraising, Save The Children Indonesia memiliki program fundraising diantaranya, yaitu; face to face fundraising, corporate fundraising, akuisi fundraising seperti; online fundraising, crowdfunding, community fundraising, dan telefundraising. Pada awalnya Save The Children Indonesia memulai aktivitas fundraising dengan menggunakan strategi bertatap muka. Kemudian, seiring dengan kebutuhan Save The Children Indonesia yang semakin bertambah, Save The Children Indonesia melakukan pertimbangan dengan mengembangkan strategi fundraising lain yang dijalankannya pada saat ini. Strategi fundraising yang dilakukan oleh Save The Children Indonesia ini memiliki cara yang konsisten berfokus terhadap tujuannya dalam mengkampanyekan isu-isu terkait dengan hak anak dalam penggalangan dana yang dilakukan.

Pada dasarnya strategi fundraising yang dilakukan oleh organisasi pelayanan sosial dapat dikembangkan menjadi strategi yang inovatif dan efektif karena dibutuhkan dalam menghimpun donor yang berkelanjutan untuk menjalankan setiap kegiatannya. Menurut, Sargeant (2010) fundraising yang biasa digunakan oleh organisasi pelayanan sosial diantaranya; dialogue fundraising, corporate fundraising, multichannel fundraising dan retention and development donor. Namun, disisi lain Young, et.al (2007) 
menjelaskan berbagai bentuk strategi fundraising yaitu; strategi penggalangan dana perseorangan, perusahan, komunitas, internet, dan telepon. Selanjutnya, dalam pembahasan ini peneliti menggunakan konsep dari Sargeant (2010) tersebut, yaitu; dialogue fundraising, corporate fundraising, multichannel fundraising dan retention and development donor yang akan disinergikan dengan konsep yang disampaikan oleh Young, et al (2007).

Berdasarkan dari latar belakang yang telah diuraikan, penerapan strategi fundraising yang dilakukan oleh Save The Children Indoneisa dapat memberikan pengetahuan baru untuk organisasi pelayanan sosial yang ingin melakukan strategi fundraising serupa. Beberapa penelitian terkait dengan fundraising telah dilakukan sebelumnya, diantaranya terdapat Akbar (2013), melakukan penelitian mengenai pelaksanaan fundraising pada organisasi pelayanan sosial. Tujuan penelitian ini untuk mengetahui dan mendeskripsikan mengenai tools fundraising di dalam organisasi pelayanan sosial yang terdiri dari; fundraising people, fundraising skills, fundraising equipment and technology. Begitupula dengan penelitian yang dilakukan dari Hendriansjah (2014), dalam penelitiannya yang terkait dengan proses crowdfunding yang dilakukan oleh \#SaveMaster dan Yayasan KitaBisa bagi sekolah masjid terminal (master) kedalam aspek kerjasama, kolektif, perhatian, kepercayaan dan kerjasama.
Berkaitan dengan penelitian yang dilakukan sebelumnya, dapat diketahui bahwa penelitian sebelumnya membahas mengenai pelaksanaan fundraising dan proses crowdfunding sudah diketahui. Dari pemaparan tersebut, maka belum diketahui strategi-strategi fundraising yang dilakukan oleh Save The Children Indonesia. Sehingga, perlu adanya kajian yang berbeda yaitu terkait dengan strategi-strategi fundraising dalam organisasi pelayanan sosial. Maka peneliti melakukan penelitian terkait dengan strategi fundraising yang dilakukan oleh organisasi pelayanan sosial yaitu Save The Children Indonesia guna memperkaya bahan kajian, menambah khazanah dan ilmu pengetahuan. Sehingga, perlu untuk dilakukan penelitian untuk menggali staretgi fundraising yang dilakukan oleh Save The Children Indonesia. Oleh karena itu, penelitian ini dilakukan dengan pertanyaan pokok: Bagaimana penerapan strategi fundraising di Save The Children Indonesia.

\section{PERMASALAHAN}

Bagaimana penerapan strategi fundraising di Save The Children Indonesia. Dalam hal ini, terdapat empat strategi fundraising yang biasanya dilakukan oleh organisasi pelayanan sosial dalam mencapai tujuannya, yaitu:

1.Bagaimana strategi dialogue fundraising di Save The Children Indonesia? 
2.Bagaimana strategi corporate fundraising di Save The Children Indonesia?

3.Bagaimana strategi multichannel fundraising di Save The Children Indonesia?

4.Bagaimana strategi retention and development donor di Save The Children Indonesia?

\section{METODE}

Metode penelitian yang digunakan dalam penelitian ini adalah metode penelitian deskriptif dengan pendekatan kualitatif. Peneliti menggunakan pendekatan kualitatif karena ingin mengetahui sejauh mana penerapan strategi fundraising yang dilakukan oleh Save The Children Indonesia. Selain itu, melalui pendekatan kualitatif ini lebih tepat digunakan karena dapat diperoleh informasi yang lebih mendalam dan terperinci mengenai penerapan strategi fundraising yang dilakukan oleh Save The Children Indonesia. Teknik penelitian yang digunakan dalam penelitian ini adalah studi kasus. Teknik pengumpulan data yang digunakan adalah wawancara mendalam, observasi nonpartisipasi, studi kepustakaan dan studi dokumentasi. Teknik analisis data yang digunakan adalah reduksi data, penyajian data (display data), dan penarikan kesimpulan. Penelitian ini melibatkan sembilan informan, yang terdiri dari, pengurus dalam unit divisi fundraising, fundraiser, donatur individu dan penerima donasi. Penentuan informan dilakukan berdasarkan tujuan penelitian untuk menggali lebih dalam mengenai penerapan strategi fundraising yang dilakukan oleh Save The Children Indonesia.

\section{HASIL PENELITIAN DAN PEMBAHASAN}

Save The Children Indonesia merupakan salah satu jenis organisasi pelayanan sosial yang berfokus pada kegiatan dan program-program yang terkait dalam membantu anak-anak mendapatkan hakhaknya. Hal ini seperti yang dikemukakan oleh Friedlander dalam (Wibhawa, 2010:124) bahwa salah satu jenis dan karakteristik pelayanan sosial dalam organisasi sosial yaitu terkait dengan pelayanan kesejahteraan anak (child welfare service). Sehinga, dalam hal ini Save The Children Indonesia merupakan organisasi pelayanan sosial yang termasuk ke dalam jenis dan karakteristik Human Service Organization (HSO) terkait dengan pelayanan kesejahteraan anak.

Dalam menjalankan setiap kegiatannya, Save The Children Indonesia tidak dapat selalu bergantung dari donor Internasional sehingga Save The Children Indonesia melakukan kegiatan fundraising untuk membiayai kegiatannya tersebut, karena menurut (Gronbjerg dalam Hasenfeld, 1992) organisasi pelayanan sosial dapat mengusahakan pembiayaannya melalui donasi, pembiayaan pribadi ataupun bantuan dari orang ketiga. Dalam kegiatan fundraising yang dilakukan oleh Save The Children 
Indonesia ini berupaya menggunakan strategistrategi fundraising yang disesuaikan dengan kebutuhan dan tujuannya yang berfokus pada kegiatan anak tersebut. Sejalan dengan Kettner (2002) pendanaan yang dilakukan oleh organisasi pelayanan sosial telah dirumuskan sesuai dengan tujuan organisasi.

Penerapan strategi fundraising yang dilakukan oleh Save The Children Indonesia. Save The Children Indonesia menerapkan strategi fundraising mengacu pada (Sargeant, 2010), diantaranya yaitu: strategi face to face fundraising (dialogue fundraising), corporate fundraising, akuisisi (multichannel fundraising) dan retention and development donor. Pada awalnya, Save The Children Indonesia menggunakan satu strategi saja yaitu; strategi face to face. Namun, Save The Children Indonesia melihat perkembangan dalam kegiatan fundraising, seperti; perkembangan donatur, teknologi maupun organisasi pelayanan sosial serupa yang melakukan kegiatan penggalangan dana karena menurut (Klein, 2011) bahwa strategi penggalangan dana setiap organisasi pelayanan sosial bervariasi tergantung apa yang mereka capai dan disesuaikan dengan keadaannya. Strategi fundraising ini dilakukan oleh Save The Children Indonesia dalam menciptakan sumber-sumber pendanaan yang mandiri dan jangka panjang. Selain itu, tujuan lain Save The Children Indonesia menerapkan strategi fundraising sejalan dengan Norton
(2002) yaitu memiliki peranan penting untuk menentukan keberlanjutan organisasi pelayanan sosial dalam menjalankan setiap aktivitasnya.

Penerapan strategi fundraising yang dilakukan oleh Save The Children Indonesia saat ini berupaya untuk memperkenalkan profile dan kegiatan kampanye Save The Children Indonesia kepada masyarakat luas. Hal ini dilakukan selain untuk mendapatkan pendanaan jangka panjang serta dapat sebagai peluang dalam memperkenalkan Save The Children Indonesia kepada masyarakat. Seperti yang dikemukakan oleh Kotler (1995:427) bahwa strategi penggalangan dana dalam organisasi dapat dilihat melalui pendekatan inkramnetal, pendekatan kebutuhan dan pendekatan peluang. Dalam hal ini, Save The Children Indonesia menggunakan tiga pendekatan tersebut.

Selain itu, penerapan strategi fundraising yang dilakukan oleh Save The Children Indonesia melibatkan aspek-aspek yang terdiri dari pendekatan visi dan misi dari Save The Children Indonesia, berupaya dalam menciptakan hubungan dan komunikasi yang baik antara pihak Save The Children Indonesia dengan para donatur dan selalu berupaya dalam membangun jaringan, seperti; melakukan kemitraan dengan perusahaan, mengajak individu dalam berdonasi baik secara langsung maupun melalui media internet. Hal ini sesuai dengan apa yang 
disebutkan Quebrol, et al (2002) terkait penggalangan dana sebagai suatu proses melibatkan tiga konsep, yaitu: Organizational Management and Development, Communication and Prospecting dan Relationship building.

\section{Strategi Dialogue Fundraising}

Strategi dialogue fundraising ini dilakukan oleh Save The Children Indonesia karena dirasa Save The Children Indonesia merupakan strategi yang efektif dalam memperkenalkan Save The Children Indonesia dan memperoleh dana. Dalam hal ini, Save The Children Indonesia sering menyebut strategi dialogue fundraising dengan sebutan strategi face to face karena Save The Children Indonesia dalam berkampanye dan memperkenalkan kepada masyarakat terkait profil, program dan kegiatan yang dilakukan oleh Save The Children Indonesia. Dalam strategi ini terdapat interaksi dan keterlibatan langsung calon donor dengan fundraiser ketika fundraisier mempresentasikan program kegiatan Save The Children Indonesia dan mengajak langsung mereka untuk berdonasi di Save The Children Indonesia. Hal ini sebagaimana yang dikemukakan oleh (Sargeant, 2010:260) strategi dialogue fundraising ini dapat juga disebut strategi tatap muka untuk membujuk masyarakat berdonasi melalui komunikasi langsung dan interaksi percakapan.
Save The Children Indonesia dengan menggunakan strategi bertatap muka tersebut, fundraiser dapat mempresentasikan program melalui interaksi langsung setidaknya sebanyak 15 orang yang dilakukan oleg seorang fundraiser dan fundraiser dapat mengajak masyarakat terlibat langsung dalam berdonasi minimal 2 orang dengan nominal masing-masing sebesar Rp. 100.000,-. Sejalan dengan Young, et al (2007:179) bahwa strategi ini adalah salah satu sumber pendanaan yang paling mudah dilakukan dan mendapatkan jumlah uang yang besar. kegiatan face to face fundraising Save The Children Indonesia ini, biasanya dilakukan di mall atau pusat perbelanjaan di Jakarta. Alasan pemilihan tempat di pusat perbelanjaan atau mall karena selalu ramai dikunjungi oleh masyarakat. Dalam hal ini, juga memudahkan masyarakat yang ingin berdonasi tetapi tidak sempat datang langsung dan bingung untuk menyalurkan donasinya. Oleh karena itu, Save The Children Indonesia membuka booth di tempat umum yaitu di mall atau di pusat perbelanjaan untuk memudahkan donatur untuk berdonasi di Save The Children Indonesia. Untuk memudahkan masyarakat dalam mengenali identitas Save The Children Indonesia dalam melakukan face to face fundraising di pusat perbelanjaan, para fundraiser (penggalang dana) Save The Children Indonesia mengenakan rompi berwarna merah yang berlogo Save The Children Indonesia, mengenakan ID card dan 
membawa folder map yang berisi materi kampanye dari Save The Children Indonesia. Hal tersebut merupakan salah satu identitas yang diciptakan oleh Save The Children Indonesia sebagai upaya untuk menarik perhatian masyarakat untuk mengenal dan menjadi pembeda Save The Children Indonesia dengan organisasi pelayanan sosial yang melakukan aktivitas fundraising serupa. Mengacu pada Lindalh (2010) fundraiser melakukan penggalangan dana dengan menggunakan strategi bertatap muka di pusatpusat perbelanjaan (mall) dan tergolong ke dalam jenis strategi private site fundraising .

Strategi bertatap muka tersebut dilakukan di pusat perbelanjaan karena target donor potensial menurut Save The Children Indonesia yaitu masyarakat dari kelas menengah atau middle class agar dapat menjadi donatur dalam jangka panjang. Selain itu, minimal berusia 21 tahun, memiliki penghasilan tetap, kartu kredit atau buku tabungan dan memiliki ketertarikan dalam kampanye dan program Save The Children Indonesia. Jenis dan target donatur yang telah ditentukan sebelumnya oleh Save The Children Indonesia dalam strategi ini dapat memudahkan Save The Children Indonesia dalam melakukan pendekatan kepada masyarakat. Hal ini sesuai dengan yang dikemukakan oleh Smith (1997) yaitu organisasi pelayanan sosial yang berfokus kepada target dan jenis dalam mencari donor dapat membantu organisasi melakukan kegiatan penggalangan dana dengan menggunakan strategi dialogue fundraising ini.

Disisi lain, dalam melakukan pendekatan kepada masyarakat tersebut melalui strategi dialogue fundraising atau face to face ini, Save The Children Indonesia didukung dengan kemampuan dan keterampilan dalam berkomunikasi yang baik yang dilakukan oleh para penggalang dana (fundraiser). Para fundraiser menggunakan komunikasi dan interaksi secara langsung kepada masyarakat untuk memberikan informasi terkait program dan kegiatan yang dilakukan oleh Save The Children Indonesia sekaligus mengajak masyarakat untuk dapat berdonasi di Save The Children Indonesia. Sesuai dengan Sprinkel (2005) yaitu organisasi pelayanan sosial harus dapat melakukan komunikasi dan dapat berinteraksi secara langsung kepada masyarakat yang dijadikan target sasaran organisasi nirlaba tersebut.

Oleh karena itu, fundraiser mempunyai peranan penting dalam melakukan pencarian sumber pendanaan melalui strategi dialogue fundraising ini. Dalam hal ini, mengacu pada Norton dan Culshaw (2000) keberhasilan penerapan strategi yang dilakukan oleh organisasi pelayanan sosial tidak luput dari peranan fundraiser yang memiliki keterampilan dan kemampuan yang baik dalam melakukan penggalangan dana. Poin utama 
yang menjadi keahlian dan keterampilan fundraiser di Save The Children Indonesia, diantaranya; memiliki komunikasi yang baik, kerjasama tim yang baik serta dapat memahami profil serta visi dan misi Save The Children Indonesia dengan baik maupun tidak pantang menyerah untuk menghadapi masyarakat yang memiliki berbagai karakter dan dalam menghadpi tolakan saat di lapangan. Hal tersebut, sesuai dengan Norton (2002:2028) untuk keterampilan menggalang dana yang harus dimiliki fundraiser diantaranya; kesungguhan membantu mewujudkan tujuan organisasi, percaya diri dan siap menghadapi tolakan, gigih, serta mampu menangkap peluang.

Keterampilan fundraiser tersebut pada akhirnya dapat meningkatkan performa Save The Children Indonesia untuk mendapatkan sumber dana dalam menjalankan program dan kegiatannya secara suistanable. Dalam hal ini, Save The Children Indonesia membekali para fundraiser dalam berinterkasi langsung dan mengajak masyarakat untuk berdonasi di Save The Children Indonesia dengan menggunakan empat tahapan, diantaranya yaitu:

\section{Approach (Pendekatan)}

Langkah pertama yang dilakukan oleh seorang fundraiser yaitu melakukan pendekatan dengan cara memberhentikan calon donatur atau Save The Children Indonesia biasa menyebut calon donaturnya yaitu calon supporter (pendukung). Untuk memberhentikan calon donatur ini, fundraiser tidak memberhentikan semua calon donatur yang lewat tetapi fundraiser melihat target sasaran yang telah ditetapkan oleh Save The Children Indonesia yaitu calon donatur yang usianya kira-kira diatas 21 tahun dan yang sudah mempunyai penghasilan cukup serta memiliki kartu kredit atau kartu tabungan.

2. Introduction (Pembukaan)

Setelah melakukan pendekatan dengan calon donatur tersebut, kemudian fundraiser memperkenalkan diri dan profile dari Save The Children Indonesia kepada para calon donatur.

3. Program Presentation (Presentasi Program)

Setelah melakukan pendekatan dengan calon donatur, kemudian fundraiser mempresentasikan program-program Save The Children Indonesia terkait dengan anak tersebut, seperti; program pendidikan, kesehatan, gizi buruk anak maupun isu-isu yang terkait anak lainnya. Pertama fundraiser menjelaskan permasalahan yang terjadi terhadap anak saat ini. Kedua, fundraiser menjelaskan mengenai solusi dari permasalahan yang dijelaskan sebelumnya. Ketiga, setelah menjelaskan mengenai solusi dari 
permasalahan tersebut, fundraiser menjelaskan hasil yang sudah di capai Save The Children Indonesia dalam mengatasi solusi dari permasalahan tersebut.

4. Asking (Mengajak Untuk Berdonasi) Kemudian, pada tahapan ini fundraiser mengajak calon donatur untuk berpartisipasi melakukan donasi di Save The Children Indonesia dan dijelaskan pula bagaimana cara berdonasi di Save The Children Indonesia.

\section{Closing (Penutup)}

Terakhir penutupan (closing). Dalam hal ini, berdasarkan pengamatan dialog yang dilakukan fundraiser yaitu mengucapkan terima kasih kepada donatur atas waktunya yang telah diberikan dan untuk dapat berpartipasi menjadi donatur Save The Children Indonesia.

Dari pernyataan tersebut sebagaimana yang dikemukakan (Sargeant, 2010: 87) bahwa tahapan seorang penggalang dana dalam melakukan kegiatan fundraising dengan menggunakan strategi dialogue fundraising ini, diantaranya; komunikasi, penyampaian pesan, presentasi, dan penggambaran penerima manfaat.

Pendekatan komunikasi yang di lakukan oleh fundraiser Save The Children Indonesia kepada masyarakat dapat mewujudkan strategi fundraising untuk memberikan hasil yang terbaik bagi organisasi. Komunikasi yang dibangun di dalam sebuah tim fundraiser terjalin dengan baik karena di dalam divisi fundraising ini bekerjasama untuk mencapai tujuan secara efektif dan efesien dalam penggalangan dana yaitu mendapatkan pendanaan sesuai dengan target yang diharapkan oleh organisasi. Mengacu pada Skidmore (1995:177) bentuk kerjasama kerjasama tim (teamwork) menjadi suatu komponen yang penting dalam organisasi pelayanan sosial, bentuk kerjasama tim akan berjalan dengan baik apabila digunakan untuk mencapai tujuan bersama.

Untuk menunjang penerapan strategi dialogue fundraising ini Save The Children Indonesia fundraiser dibekali IPad yang menggunakan sistem waysact yang berfungsi untuk memudahkan dalam memverifikasi data donatur tersebut dan mempresentasikan program kegiatan Save The Children Indonesia. Mengacu pada (Kettner, 2002) teknologi sistem dapat mendukung organisasi pelayanan sosial. Dalam hal ini yaitu dalam melakukan kegiatan penggalangan dana. Namun, disisi lain kekurangan sistem waysact tersebut hanya dapat di download dan tersinkronisasi pada IOS saja. Selain itu, sistem waysact ini juga tidak dapat digunakan ketika terkendala oleh sinyal yang buruk.

\section{Strategi Corporate Fundraising}


Strategi corporate fundraising yang dilakukan oleh Save The Children Indonesia yaitu untuk dapat mengembangkan sumber pendanaan untuk Save The Children Indonesia untuk keberlanjutan program pelayanan dalam jangka panjang dalam membangun jaringan kemitraan dengan perusahaan. Sebagaimana yang dikemukakan oleh Sargeant (2010:453) bahwa strategi corporate fundraising merupakan konteks untuk membangun pengembangan organisasi pelayanan sosial dalam bekerjasama dengan perusahaan yang mempunyai kepentingan tertentu. Dalam strategi ini pula, Melalui strategi corporate fundraising ini Save The Children Indonesia membangun jaringan kemitraan dengan perusahaan yang bertujuan untuk mendorong dan mempercepat kemajuan terhadap kampanye isu-isu yang terkait dengan anak, baik di bidang pendidikan, kesehatan, maupun perlindungan terhadap anak-anak. Selain itu, kegiatan penggalangan dana dengan menggunakan strategi corporate fundraising ini untuk menindaklanjuti program-program yang telah disusun bersama antara Save The Children Indonesia dengan perusahaan yang menjadi mitra Save The Children Indonesia agar dapat saling bersinergi satu sama lain yang disesuaikan dengan kebutuhan bersama.

\section{Meskipun demikian, Save The} Children Indonesia dalam melakukan kemitraan tetap melihat pada kesesuaian visi,misi dan nilai-nilai yang telah Save The
Children Indonesia tetapkan. Hal ini sesuai dengan konsep dari Sargeant (2010) yaitu hal tersebut dibuat untuk memperjelas dalam melakukan kerjasama yang tidak sesuai dengan visi dan misi organisasi pelayanan sosial. Oleh karena itu, Save The Children Indonesia sebelum bermitra dengan perusahaan, Save The Children Indonesia melakukan pencarian berbagai informasi profil perusahaan terkait yang akan menjadi mitra Save The Children Indonesia sebagai upaya dalam pengidentifikasian kemungkinan resiko yang terjadi melalui internet. Namun, disisi lain pencarian informasi yang dilakukan oleh Save The Children Indonesia terkadang tidak dapat semua karena keterbatasan informasi yang diperoleh dari website perusahaan tersebut.

Hal itu disebabkan beberapa informasi perusahaan yang terkadang bersifat privacy sehingga tidak dapat di publish begitu saja. Save The Children Indonesia menggunakan beberapa pendekatan dalam melakukan kemitraan yaitu Save The Children Indonesia mencari perusahaan yang mempunyai kesamaan fokus dengan Save The Children Indonesia untuk menjalin partnership. Perusahaan yang menghubungi Save The Children Indonesia untuk menjalin kemitraan dalam mengeluarkan dana CSR perusahaan tersebut. Hal ini sejalan dengan yang dikemukakan oleh Young, et al (2007: 134) seperti pengajuan proposal, promosi bersama, 
sponsorship kegiatan atau publikasi serta bantuan biaya pelayanan yang dikeluarkan.

\section{Save The Children Indonesia} mempunyai dua bentuk corporate fundraising, yaitu fundraising internasional dan fundraising local. Untuk fundraising internasional dalam strategi corporate fundraising Save The Children Indonesia. Adapun penejalsannya yaitu sebagai berikut:

\section{a. Fundraising Internasional}

Fundraising internasional ini merupakan bentuk dari corporate fundraising yang dilakukan oleh Save The Children Internasional dalam melakukan kemitraan dengan perusahaan-perusahaan skala internasional. Pada saat ini perusahaan yang merupakan global partnership dari Save The Children Internasional yaitu; IKEA, Reckitt Benkisser, Starbuck, Hyundai, Prudential, Unilever, Accenture, GlaxoSmithKline (GSK). perusahaan internasional seperti IKEA melakukan kerjasama dengan Save The Children Internasional dalam program pengembangan melawan pekerja anak. Dalam hal ini, IKEA memproduksi soft toys (mainan anak-anak) untuk kampanye terkait pendidikan. Untuk setiap pembelian mainan, uang tersebut disumbangkan untuk membantu dan mendanai program Save The Children sejak tahun 2013 di seluruh dunia, termasuk program perlindungan anak-anak di Indonesia. Selanjutnya, terdapat Unilever yang berkomitmen selama tiga tahun untuk mendukung kampanye global dari Save the Children: EVERY ONE. Kampanye ini akan menyelamatkan jutaan hidup dengan memberikan inspirasi tindakan segera terhadap pemberantasan kematian pada anak dan ibu. Kemudian, Save the Children melakukan kerjasamaa dengan perusahaan Accenture dalam membantu remaja-remaja di negaranegara seperti Indonesia, mesir, Filipina, Vietnam, Bangladesh dan Cina dalam ketrampilan dan keahlian untuk mendapatkan pekerjaan atau memulai usaha. Lalu, terdapat Prudential yang berkomitmen selama tiga tahun bersama Save The Children Internasional untuk mendukung program dan kegiatan Save the Children di Indonesia, Filipina, Kamboja dan Vietnam yang berfokus pada pengasuhan dan pendidikan usia dini. Selain itu, Save The Children Indonesia pernah melakukan pendekatan berdasarkan Cause Related Marketing (CRM). Pendekatan CRM ini yang dilakukan oleh Save The Children Indonesia yaitu; perusahaan detol pernah melakukan kerjasama dengan Save The Children Internasional.

Perusahaan Dettol tersebut menjual sabun cuci tangan di Indonesia juga kemudian di kemasan sabun cuci tangan tersebut di tambahkan stiker \#savechild sehingga masyarakat yang membeli sabun cuci tangan Dettol telah ikut berdonasi sebesar $10 \%$ dari pembelian sabun Dettol tersebut. Dettol dan Save The Children global telah mengkampanyekan kesehatan anak dan 
kebersihan. Sebagaimana pendapat

(Varadarajan dan Menon, 1988) dalam Sargeant (2010:445) kampanye CRM memiliki dua tujuan yaitu mendukung cause sosial dan meningkatkan kinerja pemasaran untuk menghasilkan penjualan sehingga perusahaan dapat memberikan donasi kepada organisasi pelayanan sosial. Dalam hal ini tujuan lain dari CRM yaitu mendapatkan pendapatan dan menyediakan pertukaran yang dapat memaksimalkan tujuan dari Save The Children Indonesia gberfokus pada pelayanan anak dengan mitra kerjasama perushaan. Sejalan dengan pendapat dari Kotler (2010) bahwa pada dasarnya kegiatan CRM menghubungkan pembelian produk atau jasa dengan fundraising (penggalangan dana) untuk cause tertentu yang diangkat perusahaan atau organisasi pelayanan sosial.

\section{b. Fundraising local}

Namun, untuk saat ini fundraising local dalam penerapannya belum dilakukan oleh Save The Children Indonesia karena di tahun kemarin kegiatan fundraising lokal ini tertunda disebabkan oleh beberapa faktor internal. Padahal untuk rencana awalnya Save The Children Indonesia pada tahun 2015 Save The Children Indonesia akan memulai bekerjasama untuk membangun kemitraan lokal corporation di Indonesia dan baru akan mulai dijalankan kembali membangun kerjasama dengan corporate lokal di pertengahan tahun 2016 ini.
Untuk melakukan kerjasama melalui kemitraan yang dibangun oleh Save The Children Indonesia tersebut, Save The Children Indonesia melakukan pengidentifikasian atas resiko untuk mengevaluasi Key Performance Indicator (KPI) serta mengantisipasi dari dampak yang dihasilkan ketika Save The Children Indonesia memutuskan untuk bermitra dengan perusahaan yang terkait. Save The Children Indonesia dalam bermitra dengan perusahaan memiliki kebijakan yang digunakan sebagai landasan dalam memutuskan melakukan kerjasama dengan perusahaan. Apapun program atau bentuk kegiatan untuk melakukan kemitraan dan kerjasama dengan perusahaan, Save The Children Indonesia tetap harus berlandaskan terhadap nilai-nilai yang dirumuskan dalam bentuk visi, misi dan tujuan Save The Children Indonesia.

Dalam hal ini, Save The Children Indonesia dalam melakukan kemitraan dengan perusahaan mempunyai kebijakan etik yaitu tidak akan mendekati perusahaan-perusahaan yang memiliki kriteria, berikut ini; perusahaan yang berhubungan dengan susu formula karena Save The Children Indonesia mempunyai program dalam mengkampanyekan ASI, perusahaan rokok, perusahaan alkohol, ada kaitannya dengan pronografi dan alkohol tidak akan di terima oleh Save The Children Indonesia dalam menjalin kemitraan dengan perusahaan tersebut. Hal ini dilakukan karena 
tidak sesuai dengan visi, misi maupun nilainilai dari Save The Children Indonesia. Kebijakan tersebut sudah menjadi landasan secara global dari Save The Children Internasional yang harus diikuti oleh seluruh Save The Children di setiap negara termasuk Save The Children Indonesia. Dalam hal ini kebijakan yang ditetapkan oleh Save The Children Indonesia telah sesuai dengan Sargeant (2010) bahwa kebijakan etis yang memetakan jenis perusahaan yang akan bekerjasama dengan organisasi nirlaba, standar perilaku yang diharapkan, dan konsekuensi dari pelanggaran (seperti penghentian kemitraan).

Sehingga, peneliti menyimpulkan terkait keseluruhan penerapan strategi corporate fundraising ini bahwa sesuai dengan konsep Steckel dan Simmons (1992) dalam Sargeant (2010: 458) yang menjelaskan dalam strategi corporate fundraising ini, organisasi pelayanan sosial harus dapat menilai hubungan dengan perusahaan yang memiliki identfikasi seperti berikut ini; lingkup dan waktu kerjasama, keterlibatan dan dukungan perusahaan maupun pegawai, dampak dari melakukan kerjasama, hasil yang dicapai, dan kualitas hubungan yang didapat dengan mitra yang terkait.

\section{Strategi Multichannel Fundraising}

Pada awal Save The Children Indonesia memulai kegiatan fundraising, Save The
Children Indonesia mengawali dengan menggunakan strategi face to face atau dialogue fundraising yang dirasa efektif oleh Save The Children Indonesia untuk mendapatkan dana. Kemudian, Save The Children Indonesia berupaya mengembangkan strategi lainnya yaitu dengan strategi multichannel fundraising karena dengan menggunakan strategi ini bertujuan dalam memperbesar sumber pendanaan yang diperoleh dan sebagai langkah antisipasi bila salah satu strategi fundraising lainnya tidak berfungsi secara efektif. Sebagaimana dengan pernyataan yang dikemukakan oleh Norton \& Culshaw (2000) bahwa organisasi pelayanan sosial memanfaatkan peluang dalam mengembangkan strategi penggalangan dana untuk memperoleh sumber pendanaan dari berbagai macam strategi fundraising lain.

Variasi dari strategi akuisisi (multichannel) yang dilakukan oleh Save The Children Indonesia diantaranya yaitu:

\section{a. Telefundraising}

Telemarketing atau telefundraising adalah cara fundraising yang dilakukan oleh Save The Children Indonesia yang dilakukan melalui telepon. Dalam hal ini, Save The Children Indonesia mendapatkan kontak masyarakat, salah satunya ketika masyarakat mengisi biodata diri dari kampanye 7 menit yang dibuat oleh Save The Children Indonesia. Kampanye \#7menit merupakan aksi yang dilakukan oleh 
Save The Children Indonesia untuk mencegah kematian bayi yang meninggal dalam setiap 7 menit terdapat 1 bayi yang meninggal dunia karena sebab yang sebenarnya dapat dicegah oleh pemerintah seperti; banyaknya daerah di Indonesia yang fasilitasnya kurang memadai, minimnya tenaga kesehatan maupun tenaga kesehatan yang kurang terampil. Melalui kampanye ini dengan pengisian petisi yang berbentuk pembatas buku tersebut, masyarakat diajak oleh Save The Children Indonesia untuk mengisi biodata diri dan menandatangani petisi tersebut sebagai upaya untuk mendesak pemerintah menghentikan kematian bayi. Selanjutnya, dengan mengisi petisi tersebut nantinya petisi tersebut akan disampaikan oleh pemerintah oleh Save The Children Indonesia.

Melalui pengisian biodata diri di dalam keterlibatan kampanye \#7menit tersebut Save The Children Indonesia mendapatkan data diri masyarakat, setelah itu tim telefundraising akan melakukan komunikasi melalui telepon dengan memberikan informasi tentang program dan kampanye yang dilakukan oleh Save The Children Indonesia dan menawarkan kepada masyarakat kesediaan untuk berdonasi dalam meningkatkan kesejahteraan anak-anak Indonesia. Ketika dihubungi melalui telepon oleh agency yang bekerjasama dengan Save The Children Indonesia, calon donatur dapat langsung memberikan donasi, cukup dengan menyebutkan jumlah donasi dan konfirmasi alat pembayaran yang akan digunakan kepada petugas di telepon, tanpa perlu mengisi formulir donasi. Namun, pada saat ini, untuk melakukan telefundraising ini Save The Children Indonesia masih bekerjasama dengan agency seperti; call center dan belum dilakukan secara in house oleh Save The Children Indonesia sendiri. Mengacu pada (Sargeant,2010) telefundraising merupakan salah satu saluran dalam strategi akuisisi yang dilakukan Save The Children Indonesia dengan menggunakan telepon untuk pemberian infromasi dan kampanye serta mengajak masyarakat dalam berdonasi.

$$
\text { b. online fundraising. }
$$

Online fundraising atau digital fundraising ini terkait dengan aktivitas fundraising yang dilakukan secara online. Masyarakat dapat berdonasi melalui website Save The Children Indonesia secara online, kemudian sign up dan setelah itu baru melakukan donasi. Donasi online memberikan pilihan cara cepat dan mudah bagi masyarakat yang aktif dengan internet dan ingin mendukung Save The Children Indonesia.Dalam hal ini Save The Children Indonesia memanfaatkan website untuk mempermudah masyarakat yang ingin sekali berdonasi di Save The Children Indonesia. Untuk online donasi yang dilakukan Save The Children Indonesia ini hanya dapat dilakukan bagi masyarakat yang menggunakan kartu kredit saja. Hal ini sesuai dengan pendapat dari (Klein, 2011: 286-288) yaitu fasilitas berupa untuk lembaran isian donatur 
dengan icon tertentu, dan diberikan suatu kalimat dibawahnya, "klik untuk berdonasi".

\section{c. Crowdfunding}

Crowdfunding adalah salah satu saluran pengumpulan dana yang dilakukan oleh Save The Children Indonesia dalam mengumpulkan uang atau biasa juga yang disebut patungan dari masyarakat untuk mewujudkan sesuatu. Hanya pemanfaatan website untuk melakukan fundraising secara crowdfunding, seperti; platform kitabisa.com. Dalam hal ini, crowdfunding yang pernah dilakukan oleh Save The Children Indonesia yaitu membantu menyediakan fasilitas belajar dan mengajar bagi anak-anak disabilitas di Kampung Sukamulya RT.01 RW.06 Desa Bongas, Cililin, Kab. Bandung Barat. Sejalan dengan Wheat (2013) bahwa penggalangan dengan menggunakan crowdfunding merupakan metode baru yang diterapkan dalam bentuk sebuah aplikasi berbasis website atau platform khusus. Save The Children Indonesia membuat video singkat serta latar belakang dan estimasi biaya yang digunakan untuk pembuatan pondok belajar disabilitas tersebut yang digunakan untuk menarik masyarakat agar dapat ikut serta berdonasi. Setiap kampanye yang terdapat di platform kitabisa.com diberikan deadline. Dalam hal ini, crowdfunding yang dilakukan oleh Save The Children Indonesia berhasil mengumpul-kan dana dari kegiatan patungan tersebut yaitu sebesar Rp. 15.853.599 dari target yang dikumpulkan sebesar dari target Rp. 13.735.000 untuk pembuatan pondok belajar untuk anak-anak disabilitas tersebut. Mengacu pada Young (2012) langkah-langkah dalam melakukan crowdfunding, yaitu:

1. Membuat proyek yang menarik

2. Buat sebuah video promosi

3. Target pendanaan yang tepat

4. Durasi promo yang tepat

Langkah-langkah melakukan crowdfunding tersebut menjadi penting dilakukan agar tujuan yang diharapkan dapat dicapai. Sehingga, dalam hal ini crowdfunding yang dilakukan oleh Save The Children Indonesia ini dapat melebihi dari target yang dicapai.

\section{d. community fundraising}

Community fundraising merupakan kegiatan penggalangan dana yang dilakukan oleh komunitas dan hasil dari kegiatan yang dilakukan oleh komunitas tersebut, diberikan oleh Save The Children Indonesia. Community fundraising yang pernah dilaku-kan yaitu kegiatan yang diadakan oleh komunitas arsenal Indonesia seperti; kegiatan lari bersama. Komunitas Arsenal tersebut menyisihkan sebagian dana untuk disumbangkan kepada Save The Children Indonesia dari hasil pendaftaran dan penjualan tiket kegiatan lari bersama. Komunitas Arsenal tersebut menyisihkan sebagian dana untuk 
disumbangkan kepada Save The Children Indonesia dari hasil pendaftaran dan penjualan tiket kegiatan lari bersama. Sebagaimana yang dikemukakan Chammbers (2005: 178) community fundraising merupakan penggalangan dana dengan melibatkan komunitas yang mempunyai visi sama untuk disumbangkan kepada organisasi pelayanan sosial untuk membangun hubungan dengan komunitas atau masyarakat maupun meningkatkan kesadaran akan manfaat terhadap program dan kegiatan yang dilakukan. Proyek Save the Children Indonesia, yang didanai oleh komunitas Arsenal saat ini sedang mengembangkan keterampilan anak muda di wilayah Bandung. Dalam hal ini, memberikan pelatihan dan keterampilan kerja kepada anak-anak muda agar dapat meningkatkan kerja tim mereka, menumbuhkan kepercayaan diri dan kepemimpinan melalui berbagai kegiatan. Community fundraising ini selain menerima sumbangan dalam bentuk uang dapat juga menerima sumbangan dalam bentuk alternatif lainnya, misalnya seperti; barang yaitu, buku bacaan untuk anak-anak, peralatan sekolah, dan baju.

Pada saat ini, Save The Children Indonesia tidak menggunakan direct mail sebagai cara dalam penggalangan dana yang dilakukan, direct mail yang digunakan Save The Children Indonesia digunakan sebagai laporan kegiatan dan pertanggungjawaban kepada donatur. Sehingga, direct mail (surat langsung) tidak digunakan oleh Save The Children Indonesia dalam saluran pendukung strategi multichannel fundraising ini sebagaimana pendapat dari Young, et al (2007) mengungkapkan bahwa saluran atau metode lain yang digunakan untuk mendekati donatur potensial secara personal merupakan terpopuler dari penggalangan dana.

\section{Strategi Retention and Development Donor}

Save The Children Indonesia melakukan strategi retention and development donor ini sebagai salah satu peluang. Sehingga, di dalam strategi ini dapat menjaga kepercayaan donatur bahkan mengembangkan donatur untuk jangka panjang sehingga Save The Children Indonesia berupaya untuk memberikan pelayanan yang terbaik kepada donatur maupun calon donatur. Kepercayaan donatur terhadap Save The Children Indonesia dapat ikut membantu meningkatkan kesadaran masyarakat untuk peduli terhadap anak-anak Indonesia yang membutuhkan bantuan terkait pelayanan pendidikan, kesehatan dan lainnya. Di dalam penerapan strategi ini, Save The Children Indonesia berupaya dalam menjalin komunikasi yang baik dan memberikan pelayanan yang baik kepada para donaturnya. Dalam hal ini, Save The Children Indonesia juga membangun komunikasi secara berkala kepada donaturnya dengan memberikan informasi terkait laporan pertanggungjawaban yang dikirimkan melalui email. Selain itu, 
terdapat pula pelayanan informasi untuk menanggapi dengan cepat keluhan, kritik dan saran para donatur. Pelayanan yang diberikan Save The Children Indonesia kepada para donatur yaitu;

\section{a. Memiliki legalitas fundraising}

Save The Children Indonesia memiliki legalitas berbadan hukum dalam melakukan kegiatan fundraising dan mempunyai izin untuk pengadaan uang dan barang (PUB) yang diatur dalam Undang-undang nomor 9 tahun 1961 tentang pengumpulan uang atau barang, dan Peraturan Pemerintah nomor 29 tahun 1980 tentang pelaksanaan pengumpulan sumbangan, penyelenggara pengumpulan uang atau barang harus melakukan izin terlebih dahulu berdasarkan wilayah. Dalam hal ini, metode dan mekanisme fundraising hingga laporan keuangan dari aktivitas penggalangan dana Save The Children Indonesia disampaikan kepada pemerintah. Selain itu, Save The Children Indonesia memiliki Standard Operasional Prosedur (SOP) dalam melakukan fundraising. SOP penggalangan dana dibuat untuk memberikan pedoman kepada pihak-pihak terkait dalam pelaksanaan penggalangan dana yang dilakukan oleh Save The Children Indonesia.

\section{b. Pelayanan Informasi}

Memberikan informasi secara lengkap kepada masyarakat ataupun donatur baik secara langsung melalui fundraiser ataupun dari website dan media sosial yang dapat diakses dengan mudah oleh masyarakat. Selain itu, donatur dapat menghubungi customer service terkait keluhan serta kritik saran kepada Save The Children Indonesia.

b. Kemudahan pembayaran

Ada berbagai cara dan alternatif yang memudahan pembayaran dalam berdonasi, antara lain; pembayaran dengan debet card, pembayaran dengan kredit card maupun pembayaran melalui internet di website Save The Children Indonesia. Selain itu, donatur yang ingin berdonasi melalui website terdapat pula pada halaman donasi yaitu Internet Payment Gateway ini menyediakan beragam cara pembayaran secara online yang tergolong mudah dan aman. Dengan begitu, masyarakat dapat dengan mudah berdonasi melalui website secara online dengan menggunakan kartu kredit. Kemudahan pembayaran dalam berdonasi di Save The Children Indonesia dengan menyediakan berbagai pilihan jumlah donasi dan alternative pembayaran memudahkan para donatur untuk berdonasi di Save The Children Indonesia.

c. Laporan pertanggungjawaban Tanggung jawab Save The Children Indonesia kepada para donaturnya dengan memberikan laporan secara berkala. Save The Children Indonesia memastikan dengan pemberian laporan secara berkala kepada donatur dan dana yang digunakan secara efisien untuk pemberian pelayanan kepada anak-anak Indonesia. Hal ini, dilakukan Save 
The Children Indonesia untuk memberikan kepercayaan dan mendapatkan loyalitas dari para donatur sehingga donatur dapat memberikan donasinya dalam jangka panjang. Laporan berkala seperti; keuangan dan informasi kegiatan yang telah dilakukan oleh Save The Children Indonesia dilaporkan kepada donatur melalui email dan newsletter terkait kegiatan-kegiatan yang dilakukan oleh Save The Children Indonesia.

d. Giving thanks (tanda ucapan terima kasih kepada donatur).

Pemberian stiker dan kartu giving thanks sebagai bentuk penghargaan dan tanda ucapan terima kasih kepada donatur yang telah terlibat dalam berpartisipasi langsung sebagai donatur di Save The Children Indonesia. Giving thanks yang diberikan kepada donatur meliputi; booklet, stiker dan welcome card. Di kartu ucapan terima kasih tersebut donatur dapat melihat program dan kegiatan yang mereka bantu dan program yang telah dilakukan oleh Save The Children Indonesia. Tujuan dari pemberian giving thanks tersebut yang dilakukan oleh Save The Children Indonesia yaitu salah satu bentuk penghargaan yang diberikan oleh Save The Children Indonesia karena telah berdonasi. Hal tersebut juga dapat menarik dan menyebarkan awareness terhadap kampanye yang dilakukan oleh Save The Children Indonesia.
Hal ini, sesuai Sargeant (2008) kepercayaan dalam konteks penggalangan dana yang dapat dilihat sebagai loyalitas donor dan hubungan organisasi pelayanan sosial yang dapat meningkatkan loyalitas donatur tersebut melalui komunikasi dengan para donaturnya, kualitas pelayanan, frekuensi organisasi melakukan komunikasi dengan donatur dan kesigapan organisasi dalam menanggapi keluhan.

Kualitas pelayanan yang dilakukan oleh Save The Children Indonesia kepada para donatur didukung dengan upaya pengembangan berbagai macam media komunikasi baik cetak maupun elektronik untuk menjembatani donatur dan pihak manajemen Save The Children Indonesia. Sehingga, para donatur dan Save The Children Indonesia lebih mudah untuk melakukan interaksi terkait penyampaian informasi program dan kegiatan yang dilakukan oleh Save The Children Indonesia. Maka, hal ini sesuai dengan Norton dan Culshaw (2000) yaitu organisasi pelayanan sosial tidak hanya sekedar melakukan kegiatan fundraising semata tetapi memperhatikan hubungan komunikasi kepada para donaturnya.

Melalui komitmen yang diberikan Save The Children Indonesia dengan menjaga kualitas pelayanan dan loyalitas para donaturnya yang telah berdonasi di Save The Children Indonesia ini membuat masyarakat lebih loyalitas lagi terhadap Save The Children 
Indonesia dengan menjadi donatur dalam jangka panjang sesuai yang diharapkan oleh organisasi. Sejalan yang telah dikemukakan oleh Norton (2002:474) bahwa hubungan dalam menarik perhatian dan menjaga kepercayaan masyarakat dapat menciptakan iklim yang baik bagi organisasi.

Hubungan baik yang dilakukan oleh organisasi pelayanan sosial dapat dilakukan dengan cara melibatkan donatur dalam program dan kegiatan yang dilakukan tersebut. Namun, pada saat ini Save The Children Indonesia belum pernah melibatkan donatur individu dalam kegiatan yang dilakukannya karena penggalangan dana yang dilakukan oleh Save The Children Indonesia baru berjalan 1,5 tahun. Pattey (2008) mengungkapkan bahwa keterlibatan donatur adalah langkah yang paling penting sebagai kesempatan dan peluang organisasi pelayanan sosial untuk menarik kepercayaan publik.

\section{KESIMPULAN}

Berdasarkan pada hasil penelitian dan pembahasan yang telah diuraikan sebelumya, mengenai penerapan strategi fundraising di Save The Children Indonesia diperoleh kesimpulan sebagai berikut:

1. Strategi Dialogue Fundrasising

Pada penerapan strategi dialogue fundraising yang dilakukan oleh Save The Children Indonesia ini melalui proses tatap muka dari donor potensial Save The Children Indonesia. Sehingga, melalui strategi ini dapat mengumpulkan pendanaan sendiri dan mengurangi ketergantungan dengan lembaga donor. Penerapan strategi dialogue fundraising di Save The Children Indonesia ini tidak luput dari keterampilan, pengetahuan dan sikap para fundraiser ketika melakukan pendekatan kepada masyarakat untuk mengajak masyarakat berdonasi di Save The Children Indonesia. Meskipun para fundraiser tersebut sering menghadapi tolakan dari masyarakat ketika mencoba melakukan pendekatan dan mengajak masyarakat melalui interaksi langsung untuk mensosialisasikan dan mengajak berdonasi di Save The Children Indonesia tetapi fundraiser tetap gigih dan tidak mudah menyerah. Hal ini disebabkan karena sebagian besar masyarakat belum mengetahui Save The Children Indonesia sebagai organisasi pelayanan sosial internasional yang berfokus memberikan pelayanan kepada anakanak. Sehingga, melalui strategi dialogue fundraising ini, Save The Children Indonesia berupaya untuk mensosialisasikan profil dan program kegiatan Save The Children Indonesia melalui kampanye terkait isu-isu anak 
baik di bidang kesehatan, pendidikan dan sebagainya. Namun, sosialisasi melalui kampanye yang dilakukan oleh Save The Children Indonesia dalam strategi dialogue fundraising ini dirasa belum optimal sehingga menyebabkan masih banyaknya masyarakat yang belum mengenal Save The Children Indonesia ini.

2. Strategi Corporate Fundaising Penerapan strategi corporare fundraising yang dilakukan oleh Save The Children Indonesia memiliki dua bentuk dalam melakukan kemitraan dengan perusahaan, yaitu; kemitraan internasional dan lokal. Pada saat ini Save The Children Indonesia mendapatkan bantuan dana dari kemitraan Internasional ini yang dilakukan oleh Save The Children Internasional (global). Melalui, kemitraan internasional ini Save The Children Indonesia mendapatkan dukungan terhadap program-program yang dijalankan dalam waktu yang telah disepakati oleh Save The Children Indonesia dan mitra yang terkait. Disisi lain, Save The Children Indonesia dalam melakukan kemitraan juga mempunyai kebijakan yang secara tegas menolak perusahaan yang tidak sesuai dengan visi, misi, maupun nilainilai dari Save The Children Indonesia dalam kegiatan pelayanan yang ramah terhadap anak tersebut. Pada penerapan strategi corporate fundraising ini, Save The Children Indonesia saat ini belum melakukan kerjasama dengan jaringan perusahaan lokal yang ada di Indonesia yang disebabkan oleh penundaan karena permasalahan internal. Sehingga, belum diterapkannya kerjasama dengan perusahaan lokal di Indonesia tersebut, memungkinkan memiliki pengaruh terhadap eksistensi Save The Children Indonesia yang belum dikenal oleh kalangan masyarakat secara luas.

\section{Strategi Multichannel Fundraising} Penerapan strategi multichannel fundraising yang dilakukan oleh Save The Children Indonesia ini dalam mengumpulkan dana menggunakan berbagai saluran dengan pemanfaatan teknologi digital dan internet yang meliputi; telefundraising dengan penggunaan telepon, online fundraising dengan menggunakan website dan media sosial, crowdfunding dengan penggunaan platform kitabisa.com dan community fundraising dengan melakukan kegiatan bersama komunitas. Namun, dalam penerapannya strategi multichannel ini baru mulai dijalankan sekitar bulan September 2015 oleh Save The Children Indonesia karena sebelumnya sempat terkendala oleh 
infrastruktur dalam pelaksanaannya. Sehingga, pada penerapannya strategi multichannel fundraising di Save The Children Indonesia saat ini masih berfokus untuk melanjutkan kegiatan dengan menggunakan media dan saluran yang telah digunakan sebelumnya dan belum mengadakan inovasi baru terkait penerapan strategi multichannel fundraising yang dilakukan.

4. Strategi Retention and Development Donor

Penerapan strategi retension and development donor yang dilakukan oleh Save The Children Indonesia cukup mendapatkan kepercayaan para donaturnya. Hal ini dilakukan Save The Children Indonesia melalui peningkatkan kualitas pelayanan yang diberikan, seperti; kepemilikan legalitas, kemudahan mendapatkan pelayanan informasi, kemudahan pembayaran, laporan pertanggungjawaban keuangan dan kegiatan, dan giving thanks (tanda ucapan terima kasih kepada donatur). Hal ini dilakukan oleh Save The Children Indonesia dengan harapan agar para donatur dapat mempertahankan loyalitasnya dalam berdonasi jangka panjang di Save The Children Indonesia. Ketika para donatur tersebut mempunyai loyalitas dan kepercayaan yang tinggi terhadap Save The Children Indonesia maka secara otomatis dapat mempengaruhi pengembangan jumlah donasi yang diberikan kepada Save The Children Indonesia. Namun, pada penerapan strategi ini Save The Children Indonesia belum melakukan pertemuan bersama antara donatur dengan pihak Save The Children Indonesia. Padahal, dengan dilakukan acara pertemuan tersebut memungkinkan Save The Children Indonesia mendapatkan donatur baru dan loyalitas donatur dalam berdonatur di Save The Children Indonesia juga dapat meningkat.

\section{SARAN}

Berdasarkan hasil penelitian dan pembahasan mengenai penerapan strategi fundraising yang dilakukan oleh Save The Children Indonesia, pada awalnya peneliti berasumsi bahwa strategi fundraising yang dilakukan oleh Save The Children Indonesia telah berlangsung cukup lama. Namun, pada realitanya setelah melakukan penelitian ditemukan bahwa Save The Children Indonesia baru melakukan fundraising dan menggunakan strategi fundraising pada tahun 2014. Selain itu, peneliti juga baru mengetahui terkait fakta di lapangan dalam penelitian ini yaitu, pertama sebagian besar masyarakat di Indonesia belum 
mengenal brand hingga profil dan kegiatan yang dilakukan oleh Save The Children Indonesia. Kedua, Save The Children Indonesia juga belum membangun kerjasama dengan perusahaan-perusahaan lokal yang ada di Indonesia. Sehingga, dengan kerjasama yang dibangun dengan perusahaan lokal tersebut dapat menciptakan strategi pendanaan baru yang menjadi alternatif dan peluang untuk Save The Children Indonesia dalam mendapatkan dana. Keempat, Save The Children Indonesia dapat melakukan pengembangan dengan mempublikasikan dan mensosialisasikan kegiatan Save The Children Indonesia di media massa, baik itu koran, televisi ataupun pemasangan baligho terkait kampanye yang dilakukan oleh Save The Children Indonesia. Keempat, pada saat ini Save The Children Indonesia belum pernah mengadakan kegiatan atau acara bersama donatur individu. Oleh sebab itu, sebaiknya diselenggarakan acara bersama donatur untuk mempertahankan loyalitas donatur kepada Save The Children Indonesia. Acara bersama donatur tersebut dapat juga dilakukan Save The Children Indonesia dengan melibatkan donatur tetap untuk turun di lapangan dan melihat program dan kegiatan yang dilakukan oleh Save The Children Indonesia terkait penyaluran donasi yang dilakukan oleh Save The Children Indonesia. Dengan hal ini, maka donatur juga dapat memberikan masukan kepada Save The Children Indonesia mengenai penyaluran donasi yang dilakukan oleh Save
The Children Indonesia.

Dalam hal ini, maka dirumuskan rekomendasi yang dapat dijadikan bahan pertimbangan dalam upaya peningkatan dan perbaikan strategi fundraising yang dilakukan oleh Save The Children Indonesia, yaitu; Save The Children Indonesia dapat melakukan optimalisasi terhadap sosialiasi brand image Save The Children Indonesia kepada masyarakat dengan melakukan pengembangan inovasi campaign yang telah dilakukan pada setiap strategi fundraising. Hal ini dilakukan agar masyarakat luas mengetahui profil, program dan kegiatan yang dilakukan oleh Save The Children Indonesia. Sehingga, ketika masyarakat sudah mengenal Save The Children Indonesia maka masyarakat juga lebih mudah diajak untuk berpartisipasi dalam berdonasi di Save The Children Indonesia. Selain itu, Save The Children Indonesia juga dapat memulai membangun jaringan untuk melakukan kemitraan dengan perusahaanperusahaan lokal yang ada di Indonesia dan melihat peluang dalam membangun kemitraan dengan perusahaan lokal yang tetap disesuaikan dengan visi, misi dan nilai-nilai Save The Children Indonesia. Sehingga, dengan kerjasama yang dibangun dengan perusahaan lokal tersebut dapat menciptakan strategi pendanaan baru yang menjadi alternative untuk Save The Children Indonesia. Disisi lain, Save The Children Indonesia juga dapat mengenalkan brand Save The Children 
Indonesia ke masyarakat Indonesia mengenai program dan kegiatan yang dilakukan melalui kerjasama dengan perusahaan lokal tersebut. Dalam hal ini, donatur tetap dan perusahaan terkait yang menjadi mitra dari Save The Children Indonesia dapat melihat langsung penyaluran donasi yang dilakukan oleh Save The Children Indonesia

Oleh karena itu, peneliti mencoba menyarankan sebagai pertimbangan untuk strategi fundraising yang dilakukan oleh Save The Children Indonesia. Saran ini ditujukan untuk Save The Children Indonesia dalam mengoptimalkan strategi fundraising dan personal branding kepada masyarakat Indonesia dengan berkolaborasi bersama perusahaan-perusahaan lokal yang ada di Indonesia agar menciptakan kerjasama dan peluang sumber pendanaan baru bagi Save The Children Indonesia serta memperkenal-kan Save The Children Indonesia dengan meningkatkan awareness masyarakat Indonesia terhadap kampanye Save The Children Indonesia yang berfokus terhadap anak-anak Indonesia. Dalam hal ini peneliti memberikan sebuah gagasan terkait dengan program Corporate Fundraising as a Fundraising Strategy: "Save a Child, Galang Dana Pembuatan Rumah Pintar Untuk Anak Jalanan".

Hasil yang ingin dicapai dalam kegiatan tersebut yaitu Masyarakat dapat mengenal kehadiran Save The Children
Indonesia sebagai organisasi pelayanan sosial internasional yang berfokus bidang pelayanan terhadap anak-anak. Sehingga, dengan begitu masyarakat menjadi tergerak untuk ikut berpartisipasi dalam berdonasi di Save The Children Indonesia. Kemudian, terjalinnya kerjasama aktif dengan perusahaan lokal yang ada di Indonesia, sehingga diharapkan akan dapat menjadi peluang dalam pendanaan jangka panjang dan untuk keberlanjutan program.

\section{DAFTAR PUSTAKA}

\section{Buku :}

Chambers, Donald. 2005. Social Policy and Social Programs. Boston: Pearson Education, Inch

Creswell, John. 2013. Research Design: Pendekatan Kualitatif, Kuantitatif, dan Mixed, Edisi Ketiga. Yogyakarta: Pustaka Pelajar.

Hasenfeld, Y. 1983. Human service organization (2nd ed.). New Jersey: Practice Hall Inc.

.1992. Human service as complex organization ( $3 r d$ ed.). USA: Sage Publication.

Kalida, Muhsin. 2004. Pola dan Strategi Fundraising Dalam Pengembangan Lembaga Sosial. Yogyakarta.

Kettner. 2002. Achieving Excellence in The Management of Human Service Organizations. Boston: Allyn and Bacon 
Klein, Kim. 2011. Fundraising for Social Change ( $6^{\text {th }}$ edition). San Fransisco: Josey Bass

Kotler, Philip, Ned Roberto, dan Nancy Lee. 2000. Social Marketing: Improving The Quality of Life Second Edition. SAGE Publications, Inc.

Lindahl, Wesley E., 1992. Strategic Planning for Fund Raising: How to Bring in More Money Using Strategic Resource Allocation, San Francisco, Calif.: Jossey-Bass

Moelong, Lexy J. 1998. Metode Penelitian Kualitatif. Bandung : Remaja Rosdakarya

Norton, Michael. 2002. Menggalang Dana: Penuntun bagi Lembaga Swadaya Masyarakat dan Organisasi Sukarela di Negara-Negara Selatan (Masri Maris, Penerjemah) Jakarta: Yayasan Obor Indonesia

and Culshaw M.2000.

Getting started in fundraising, New

Delhi: Sage Publications India Pvt, Ltd

Pattey, G.Janice. 2008. Non Profit Fundraising Strategy. New Jersey: John Wiley \& Son. Inch

Sargeant, Adrean. 2010. Fundraising Principal and Practices. Sans Fransisco: John Wiley \& Sons, Inc. All rights reserved.

Skidmore,Rex A,. 1995. Social Work Administration Dynamic Management and Human Relationships. United Stated: Alyn \& Bacon

Sprinkel, Kay.2005. Beyond Fundraising New Strategies For Non Profit Innovation and Investment ( $2^{\text {nd }}$ edition). Canada: John \& Wiley \& Sons, Inc

Wheat, R. E., Wang, Y., Byrnes, J. E., \& Ranganathan, J. 2013. Raising money for scientific research through crowdfunding.Trends in ecology \& evolution, 28(2), 71-72.

Wibawa,Budi, Dkk. 2010. Dasar-Dasar Pekerjaan Sosial. Bandung: Widya Padjadjaran

Young, Joyce, Ken W. \& John S. (2007). Menggalang dana untuk organisasi nirlaba. Jakarta: PT. INA PUBLIKATAMA.

T. E. 2012. The Everything Guide to Crowdfunding: Learn how to use social media for small-business funding. Avon, MA, United States of America: Adams Media.

\section{Karya Ilmiah:}

Akbar, M.K.(2013). Studi Deskriptif Pelaksanaan Fundraising Dalam Lingkup Human Service Organization Di Yayasan Bustanul Ulum Di Kawasan Desa Cikadut Kecamatan Cimenyan, Kabupaten Bandung. Skripsi. Kesejahteraan Sosial UNPAD.

Hendriansjah, Stefani. (2014). Proses Crowdfunding oleh \#SaveMaster dan Yayasan Kita Bisa Bagi Sekolah Masjid Terminal (Master), Depok. Skripsi. Kesejahteraan Sosial UNPAD

Irfan, Maulana (2011). Komunikasi Pemasaran Organisasi Sosial. Artikel. Ilmu Kesejahteraan Sosial, Fakultas Ilmu Sosial \& Politik, Universitas Padjadjaran diakses melalui http://kesos.unpad.ac.id/2011/09/27/ko munikasi-pemasaran-organisasi-sosial/ 
pada tanggal 6 Januari 2016, pukul 14.30 WIB

Kilbey, Brian (2008). Fundraising For Social Service. Journal. Associate Professor, Department of Social Development, University of Cape Town

Sargeant, A. and Woodliffe, L. (2007)

Building Donor Loyalty: The

Antecedents and Role of Commitment in the Context of Charity Giving,' Journal of Nonprofit and Public Sector Marketing .(2008). Donor Retention: What Do We Know and What Can We Do About It? . Journal. Indiana University melalui

http://www.afpnet.org/files/contentdocu ments/donor_retention_what_do_we_kn ow.pdf pada tanggal 17 Maret 2016, pukul 22.30 WIB

Tedham, Ashley.(2012). Charitable Giving, Fundraising, and Faith- Based Organizations: Islamic Relief World Wide and World Vision International - A Comparison. Journal. Graduate Institute of International and Development Studies

PIRAC (2002). Investing in Ourselves Giving and Fundraising In Indonesia. Paper. Asian Development Bank

\section{$\underline{\text { Publikasi elektronik }}$}

http://www.savethechildren.or.id

http://www.pirac.org

http://nasional.tempo.co/read/news/2013/12/1 8/05536269/kekurangan-dana-lsmnarkoba-bertumbangan diakses pada tanggal 3 Mei 2015, pukul 16.40 WIB

http://www.thenewage.co.za/5780-1016-53NGOs_in_crisis_over_lack_of_funding _and_staff_loses diakses pada tanggal 5 Mei 2015, pukul 19.00 WIB

http://sekolahfundraising.com/tag/perencanaa n-strategis/ dari website http:// pirac.org diakses pada tanggal 17 Juni 2015, pukul $21.00 \mathrm{WIB}$

http://indonesia.ucanews.com/2011/03/29/klin ik-tbc-ditutup-penderita-bingung/ diakses pada tanggal 20 Juni 2015, pukul 17.30 WIB

http://www.rri.co.id/post/berita/206644/nasio nal/kemensos_upayakan_penyelenggara an_pengumpulan_uang_atau_barang_ya ng_sesuai_aturan.html diakses pada tanggal 15 Desember 2015 